\title{
In Situ Bioremediation of Chlorinated Solvent with Natural Gas
}

by

D. E. Rabold

Westinghouse Savannah River Company

Savannah River Site

Aiken, South Carolina 29808

A document prepared tor HOME PAGE

DOE Contract No. DE-AC09-89SR18035

This paper was prepared in connection with work done under the above contract number with the U.S.

Department of Energy. By acceptance of this paper, the publisher and/or recipient acknowledges the U. S. Government's right to retain a nonexclusive, royalty-free license in and to any copyright covering this paper, along with the right to reproduce and to authorize others to reproduce all or part of the copyrighted paper. 


\section{DISCLAMMIER}

Portions of this document may be illegible in electronic image products. Images are produced from the best available original document. 


\section{DISCLAIMER}

This report was prepared as an account of work sponsored by an agency of the United States Government. Neither the United States Government nor any agency thereof, nor any of their employees, makes any warranty, express or implied, or assumes any legal liability or responsibility for the accuracy, completeness, or usefulness of any information, apparatus, product, or process disclosed, or represents that its use would not infringe privately owned rights. Reference herein to any specific commercial product. process, or service by trade name, trademark, manufacturer, or otherwise does not necessarily constitute or imply its endorsement, recommendation, or favoring by the United States Government or any agency thereof. The views and opinions of authors expressed herein do not necessarily state or reflect those of the United. States Government or any agency thereof.

This report has been reproduced directly from the best available copy.

Available to DOE and DOE contractors from the Office of Scientific and Technical Information, P. O. Box 62, Oak Ridge, TN 37831; prices available from (615) $576-8401$.

Available to the public from the National Technical Information Service, U: $S$. Department of Commerec, 5285 Port Royal Rd., Springfield, VA 22161 


\section{In Situ Bioremediation of Chlorinated Solvent With Natural Gas}

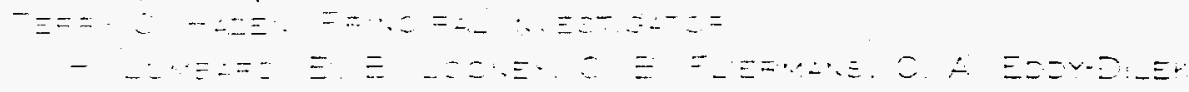

n" the cover:

Our patented bioremediation system (inset) is being used to remove chlorinated solvents in subsurface water and sediment.

According to the Envirommental Protection Agency, chlorinated solvents are extremely nidespread contaminants.

We have shown that such contamination can be completely eliminated in situ using injection of natural gas (as a microbial mutrient) through an innovative configuration of horizontal wells. 
1. Submitting organization: Westinghouse Savannah River Technology Center

Address:

Savannah River Site

City/State/Zip/Country:

Aiken, SC 29808 (USA)

Submitter's name:

Terry C. Hazen

Phone/Fax:

$803 / 725-6413 ; 803 / 725-6223$

Affirmation: I affirm that all information submitted as a part of, or supplemental to, this entry is a fair and accurate representation of this product.

Submitter`s signature:

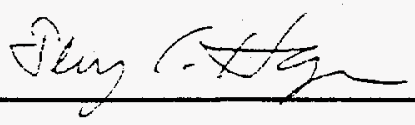

2. Joint entry with

Address:

City/State/Zip/Country:

Submitter's name:

Phone/Fax:

3. Product Name: In Situ Bioremediation of Chlorinated Solvent With Natural Gas

4. Briefly describe what the entry is.

This patented bioremediation technology combines natural gas injection and air stripping to stimulate microbes to completely degrade and remove chlorinated solvents in situ in groundwater and sediment in a short time, at a low cost, without harmful side effects. This technology has global applications: almost every highly developed country in the world has used chlorinated solvents for industrial purposes and suffers from the concomitant contamination.

5. When was this product first marketed or available for order? (month/year)

March 1994

6. Inventor or Principal Developer: Terry C. Hazen. Ph.D

Position: Fellow Scientist

Organization: Westinghouse Savannah River Technology Center

Phone: $\quad 803 / 725-6413$

Fax: $803 / 725-6223$

7. Product price: $\$ 6.000 /$ license If the price is proprietary, list it and check here:

8. Do you hold any patents on this product?

Yes $⿴$ № $\square$

Do you have any patents pending?

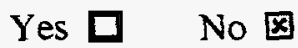

Do others hold patents on this product or a similar product line? Yes $₫ \quad$ No 
9. Describe your product's primary function.

Bioremediation with natural gas injection harnesses the natural cleansing capacity of the environment to decontaminate underground water and soil. What we did was stimulate naturally occurring microbes to degrade chlorinated solvents, such as trichlorethylene (TCE) and tetrachlorethylene (PCE). This technology represents a significant breakthrough in environmental remediation: we showed that resistant contaminants can be degraded very effectively in situ by injection of natural gas (methane).

Furthermore, we proved this technology to be much more efficient and cost effective than any preexisting commercial technique.

Our technique remediates to $2 \mathrm{ppb}$ (undetectable levels), rather than to $1000 \mathrm{ppb}$, as is common through other remediation techniques in a heterogeneous environment. Our technique collapses the time needed to achieve $95 \%$ contaminant removal from $>10$ years to $<4$ years. The cost of remediation falls from as much as $\$ 38 / \mathrm{hb}$ to less than $\$ 21 / \mathrm{lb}$ when using our technique.

Chlorinated solvent contaminants are known to exist in thousands of sites in the U.S. and in industrialized countries around the world. Such contamination damages the ecosystem and poses serious potential health problems if local groundwater is used as a source of drinking water or irrigation water or if the soil is used for growing crops. Contamination of groundwater by organic compounds is recognized as one of the most important pollution problems of the industrialized nations. It is estimated that more than $15 \%$ of community drinking water in the U.S. is already contaminated with chlorinated hydrocarbons.

The specific microbes used in this process are called methanotrophs-methane oxidizing bacteria. Methanotrophs exist everywhere, but generally in populations too small to have an effect on coexisting contamination. We injected very low concentrations of methane through a well drilled horizontally below the water table in a test site to stimulate the growth of the bacterial population. We withdrew air through an upper, parallel well to increase air flow. We determined that methanotrophic bacteria could effectively remove chlorinated solvents and their breakdown products with no harmful side effects. This process cut the time for in situ cleanup in half.

The concept of methane-induced bioremediation had been demonstrated in the laboratory, but no in situ demonstration had been done, nor had the wide-scale effectiveness or cost of the technology been determined. Proving this concept was the final task of a continuing Savannah River Site technology project that focused on the selection, full-scale demonstration, and evaluation of in situ environmental remediation processes for treating soil and ground water contaminated with TCE/ PCE and associated daughter products. In the final project phase, we combined biostimulation and biodegradation with an air stripping process.

We used a test bed located along an abandoned process sewer line at the Savannah River Site for this entire project. Over many years, solvents had been disposed of in a basin under the sewer. In 1986, the basin was closed and the sewer line removed. We drilled two horizontal wells in the test site: one below the water table, aira one above. The horizontal orientation was chosen to maximize the area of decontamination, since the plume was horizontal in shape, and to enhance the distribution of the microbes. Air and methane were then injected into the lower well and were withdrawn from the upper well. Methane was injected in several low concentrations to stimulate microbial growth. Samples of sediment, soil gas, and ground water were taken at regular intervals during the study to monitor progress.

Our tests showed that the methane injection caused the density of contaminant-degrading bacteria to increase by 7 orders of magnitude (10 million times). Biostimulation was immediate with injection of low concentrations of methane. Concentrations of TCE/PCE in water, soil gas, and sediment decreased by as much as $99 \%$, reaching below detectable limits. In fact, our process removed $42 \%$ more TCE than did air stripping (the underlying process) alone.

This technology demonstrated the validity of the theories of biostimulation and biodegradation to achieve effective environmental remediation. These theories were turned into methodologies that work more effectively than conventional technologies. 


\section{0a. List your product's competitors.}

Our technology includes important new concepts, such as a defined approach for injecting methane as a nutrient to stimulate and enhance microorganism breakdown of contaminants, as well as an innovative application of horizontal well drilling technology.

In situ bioremediation is a well-known process; however, many of the techniques developed so far are too costly to execute and are not effective enough to overcome barriers to commercial development. A slow-paced process, for example, or a process that produces other toxins, such as vinyl chloride, fails to overcome barriers to successful commercialization.

The principal existing method for remediation of TCE-contaminated ground water is pump and treat, followed by air stripping. Unsaturated sediment contamination can only be remediated by vapor extraction. None of these are TCE destruction technologies: the TCE is either discharged to the atmosphere or captured for subsequent disposal (incineration).

Since the overall SRS project was a collaborative effort of industry, academia, and government partners, our results were independently verified by several labs which were project participants. We determined that destruction of contaminants in situ was complete and that no harmful daughter products had been produced.

For this entry, we are comparing our technology to alternate existing remediation techniques such as pump and treat, vapor extraction, and air stripping.

10b. Supply a comparison matrix.

The comparison matrix appears on the next page.

10c. Describe how your product improves upon competitive technologies.

\section{* Our process destroys and removes contaminants in their original location.}

To remove contaminants at concentrated sites, the traditional environmental methods involve transferring toxic wastes from one medium to another - from water to air, for example.
When the total degradation into elemental components such as carbon dioxide and oxygen is required, existing methods favor incineration for breaking down polluted materials. But the public outcry over this process is so pronounced that it is no longer an attractive option.

Our technology is superior to competing technologies in several respects, but especially in that the decontamination is to drinking water levels. Figure 1 shows the location of the contaminant plume in our demonstration site and shows schematically the system we used to inject methane for subsurface microbial stimulation.

\section{* Our technology is more effective than any.} other. Our tests demonstrated that PCE was biodegraded when methane was injected into the site, even though PCE can only be degraded anaerobically. Our data proved that enough anaerobic pockets were created by the increasing biomass to allow a significant amount of anaerobic reductive dechlorination $r^{r}$ ?r.E to TCE, which was then oxidized by methanotrophs.

Determining the correct nutrient, methane, and the correct methane concentrations for biostimulation ( $1 \%$ of air or pulses of $4 \%$ of air), was just part of the total solution. Combining biostimulation with a unique nutrient delivery system is an important part of our technology. We drilled horizontal wells, which bear on both performance and cost.

The horizontal wells greatly extend the area in which the microbes can penetrate. A pair of horizontal wells can run as far as 1500 feet underground and affect an area 300 to 400 feet wide.

The actual area decontaminated during our test was about the size of a football field, 300 feet long by 150 wide by 200 feet deep. Furthermore, the horizontal wells can reach hard-to-treat places, such as beneath existing buildings and structures (such as a runway).

Bioremediation reached extremely high levels using our combined nutrient injection and well drilling concepts. Water concentrations of TCE and PCE decreased by as much as $95 \%$, reaching concentrations below detectable limits $(<2 \mathrm{ppb})$. Soil gas TCE and PCE declined by more than $99 \%$, also reaching undetectable limits. 


\section{Comparison Matrix}

\begin{tabular}{|c|c|c|c|c|}
\hline Feature & $\begin{array}{c}\text { Methane } \\
\text { Injection w/ } \\
\text { Horizontal } \\
\text { Wells }\end{array}$ & $\begin{array}{l}\text { Ground Water } \\
\text { Pump and } \\
\text { Treat }\end{array}$ & $\begin{array}{l}\text { Soil } \\
\text { Air Stripping }\end{array}$ & $\begin{array}{l}\text { Competitive } \\
\text { Advantage }\end{array}$ \\
\hline $\begin{array}{l}\text { Removes or destroys } \\
\text { volatile and nonvolatile } \\
\text { contaminants in a } \\
\text { heterogeneous environment }\end{array}$ & Yes & No & No & $\begin{array}{l}\text { Heterogeneous } \\
\text { environments are the } \\
\text { norm, so application } \\
\text { is widespread. }\end{array}$ \\
\hline $\begin{array}{l}\text { Removes or destroys } \\
\text { volatile and nonvolatile } \\
\text { contaminants in a } \\
\text { homogeneous environment }\end{array}$ & Yes & Yes & Yes & $\begin{array}{l}\text { Our method is } \\
\text { equally effective in } \\
\text { homogeneous } \\
\text { environments. }\end{array}$ \\
\hline $\begin{array}{l}\text { Produces toxic daughter } \\
\text { products or a secondary } \\
\text { waste stream }\end{array}$ & No & Yes & Yes & $\begin{array}{l}\text { Our method does not } \\
\text { produce any harmful } \\
\text { by-product. }\end{array}$ \\
\hline $\begin{array}{l}\text { Is generally acceptable to } \\
\text { the public }\end{array}$ & Yes & $\begin{array}{l}\text { Yes, except for air } \\
\text { emissions }\end{array}$ & $\begin{array}{l}\text { Yes, except for air } \\
\text { emissions }\end{array}$ & $\begin{array}{l}\text { Ours is a "Green" } \\
\text { solution. }\end{array}$ \\
\hline Is environmentally effective & $\begin{array}{l}\text { High, because it } \\
\text { destroys } \\
\text { contaminants. }\end{array}$ & $\begin{array}{l}\text { Moderate, } \\
\text { because above } \\
\text { ground treatment } \\
\text { is then needed. }\end{array}$ & $\begin{array}{l}\text { Moderate to high, } \\
\text { because air } \\
\text { emissions must be } \\
\text { addressed. }\end{array}$ & $\begin{array}{l}\text { Our technique } \\
\text { destroys } \\
\text { ants to undetectable } \\
\text { levels in place. }\end{array}$ \\
\hline $\begin{array}{l}\text { Is cost effective (estimated } \\
\text { project life cycle cost per } \\
\text { pound remediated) }\end{array}$ & $\$ 15$ to $\$ 21$ & $\$ 38$ & $\$ 32$ & $\begin{array}{l}\text { Our method halves } \\
\text { remediation costs. }\end{array}$ \\
\hline $\begin{array}{l}\text { Ease of use; ability to } \\
\text { automate }\end{array}$ & High & Moderate & Moderate & $\begin{array}{l}\text { One technician can } \\
\text { operate up to six of } \\
\text { our units with } \\
\text { minimal training. }\end{array}$ \\
\hline $\begin{array}{l}\text { Meets rigorous regulatory } \\
\text { standards (remediates to } \\
\text { drinking water levels) in } \\
\text { heterogeneous } \\
\text { environments }\end{array}$ & $\begin{array}{l}\text { Yes, to less than } 2 \\
\text { ppb }\end{array}$ & $\begin{array}{l}\text { No, reaches } \\
1000 \mathrm{ppb}\end{array}$ & $\begin{array}{l}\text { No, reaches } \\
1000 \mathrm{ppb}\end{array}$ & $\begin{array}{l}\text { Our method remedi- } \\
\text { ates to drinking water } \\
\text { levels and beyond. }\end{array}$ \\
\hline $\begin{array}{l}\text { Number of wells needed to } \\
\text { remediate a benchmark area }\end{array}$ & Two & Ten & Ten & $\begin{array}{l}\text { Using fewer wells } \\
\text { reduces cost and } \\
\text { streamlines the } \\
\text { overall effort }\end{array}$ \\
\hline $\begin{array}{l}\text { Destruction of contaminants } \\
\text { into elemental compounds }\end{array}$ & Yes, in place & $\begin{array}{l}\text { No; and requires } \\
\text { surface treatment } \\
\text { (air stripping and } \\
\text { catalytic oxida- } \\
\text { tion or GAC or } \\
\text { incineration }\end{array}$ & $\begin{array}{l}\text { No; and requires } \\
\text { GAC or } \\
\text { incineration or } \\
\text { catalytic } \\
\text { oxidation }\end{array}$ & $\begin{array}{l}\text { Our method destroys } \\
\text { contaminants in } \\
\text { place, which reduces } \\
\text { cost and is more } \\
\text { effective. }\end{array}$ \\
\hline $\begin{array}{l}\text { Time needed to achieve } \\
95 \% \text { contaminant removal }\end{array}$ & $<4$ years & $>10$ years & $>10$ years & $\begin{array}{l}\text { This method more } \\
\text { than doubles the } \\
\text { speed of remediation. }\end{array}$ \\
\hline
\end{tabular}


Sediment concentrations declined to undetectable limits as well. Results were observed in only 3 months.

Figures 2 and 3 are three-dimensional illustrations of the concentrations of chlorinated solvents before and after our demonstration. Figure 4 shows the high densities of microbes in the demonstration site after our test.

In comparison, conventional technologies usually level off at about $1000 \mathrm{ppb}$ in heterogeneous environments, a probable limitation of ground water and soil adsorption/desorption properties. Homogeneous environments are not common; therefore, finding a suitable remediation technique must be in the context of a heterogeneous environment.

Our demonstration showed that $42 \%$ more TCE/PCE was degraded and removed by our bioremediation process than by in situ air stripping alone.

A pump and treat system may not be effective over the long term at some sites because it does not remove contaminants bonding with soils and clays. The contaminants which remain slowly leach back into the cleaned up areas and ground water.

Air stripping systems also leave residual contaminants in clay soils. Vapors removed from ground water and soil require further treatment, usually some form of incineration. Offgas systems not only incur additional cost, but are not generally acceptable to the public.

\section{* Our combined biostimulation and air} stripping process is cost and time effective. In situ air stripping is more cost effective than baseline technologies (soil vapor extraction and ground water pump and treat).

The in situ bioremediation process tested was $40 \%$ less expensive than the baseline technology.

With this technology, we removed more contaminant than either in situ air stripping or pump and treat systems. The added cost of methane injection to air stripping was only $8 \%$.
As little as 900 pounds of contaminant needs to be biodegraded to offset this additional cost to the in. situ air stripping system. Further, our demonstration showed that when methane is added to a process such as air stripping, cleanup that would normally take 10 years to reach acceptable levels $(95 \%)$ could be achieved in about 4 years to undetectable levels $(<2 \mathrm{ppb})$.

This difference alone would result in a $\$ 1.5$ million savings over the conventional system for just the Savannah River Site demonstration area.

For the entire Savannah River Site, savings would be multiple millions. Since bioremediation destroys contaminants in situ, before they contaminate underlying groundwater, the cost of any pump and treat system is reduced.

When we coupled in situ bioremediation with air stripping, we saw a significant reduction in the time required to complete the remediation because bioremediation provides a second simultaneous pathway for removal (destruction) o i $i \mathrm{E}$. Also, the microbes, when stimulated by methane, reached TCE in the vadose zone and aquifer matrixes that was very difficult to remove by air stripping, and which was not removable by the pump and treat method.

- This technology is easy to use. Our system is completely automated and extremely trouble-free. It is so easy to use that one technician can operate at least six systems at once. Concurrently, the technician can be responsible for site monitoring equipment.

\section{* Conventional risks are avoided altogether.} Since in situ bioremediation technology is based on biological destruction of the contaminants at the site, risks associated with handling, transporting, treating, and storing contaminated residuals are avoided. This is a significant reduction of risk to workers and to the public.

\section{* This technology is generally acceptable.} Bioremediation techniques enjoy relatively high regulatory acceptability. Further, bioremediation is generally acceptable to the public, because it is accurately perceived to be a natural environmental cleanup solution. 
Snurce: All figures are from SRTC internal data generated during the in situ bioremediation demonst

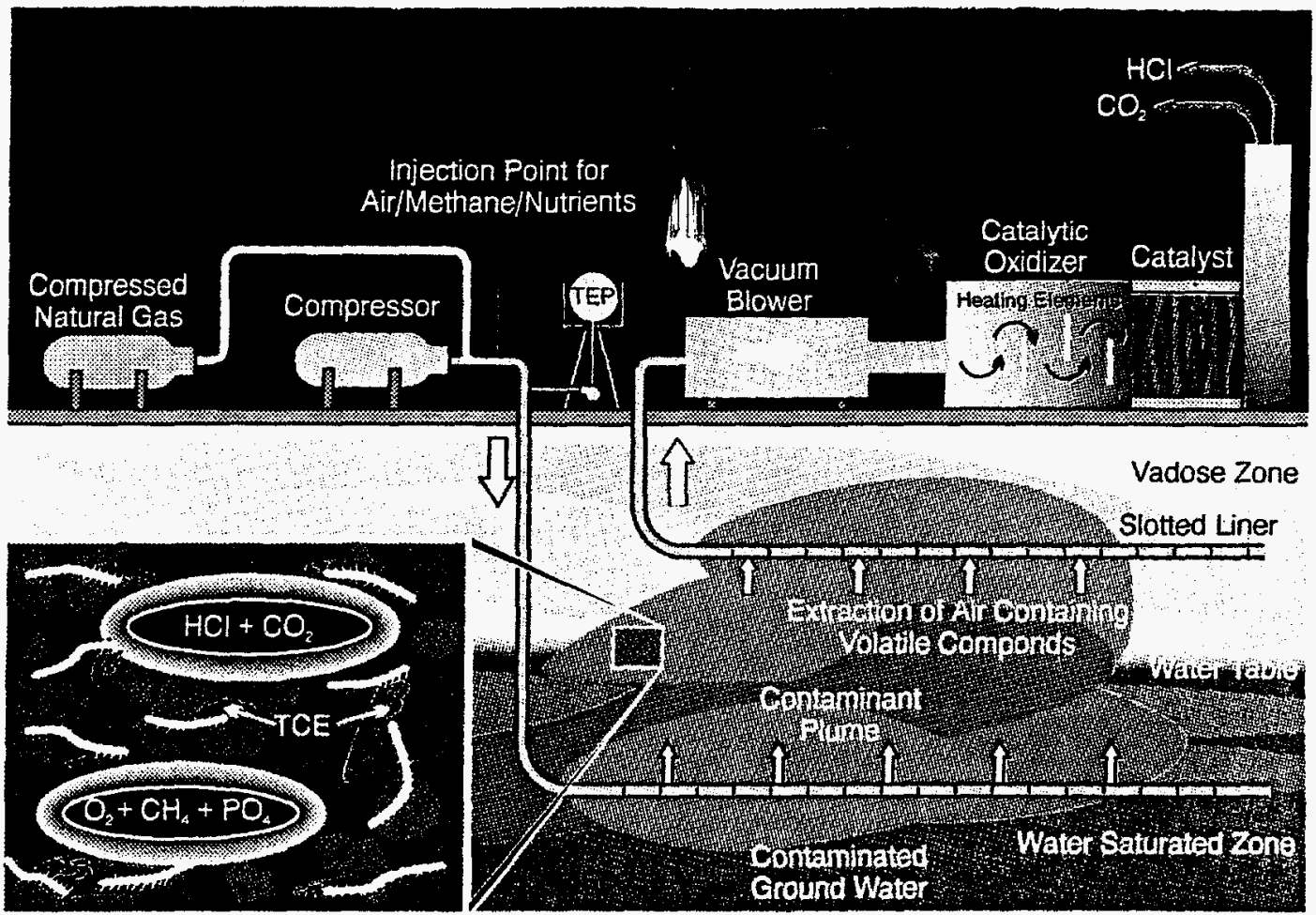

Figure 1. Schematic diagram of the methane air and nutrient injection into a horizontal well below the water table with parallel vapor extraction above the water table. The enlargement shows how oxygen and methane from the injection gas stream are taken up by methane-oxidizing bacteria in the sediment and converted into chloride and $\mathrm{CO}_{2}$. Contaminants in the vapor extracted for the initial demonstration from the unsaturated (vadose) zone was thermal catalytically converted to $\mathrm{CO}_{2}$ and chloride. This conversion step is optional.

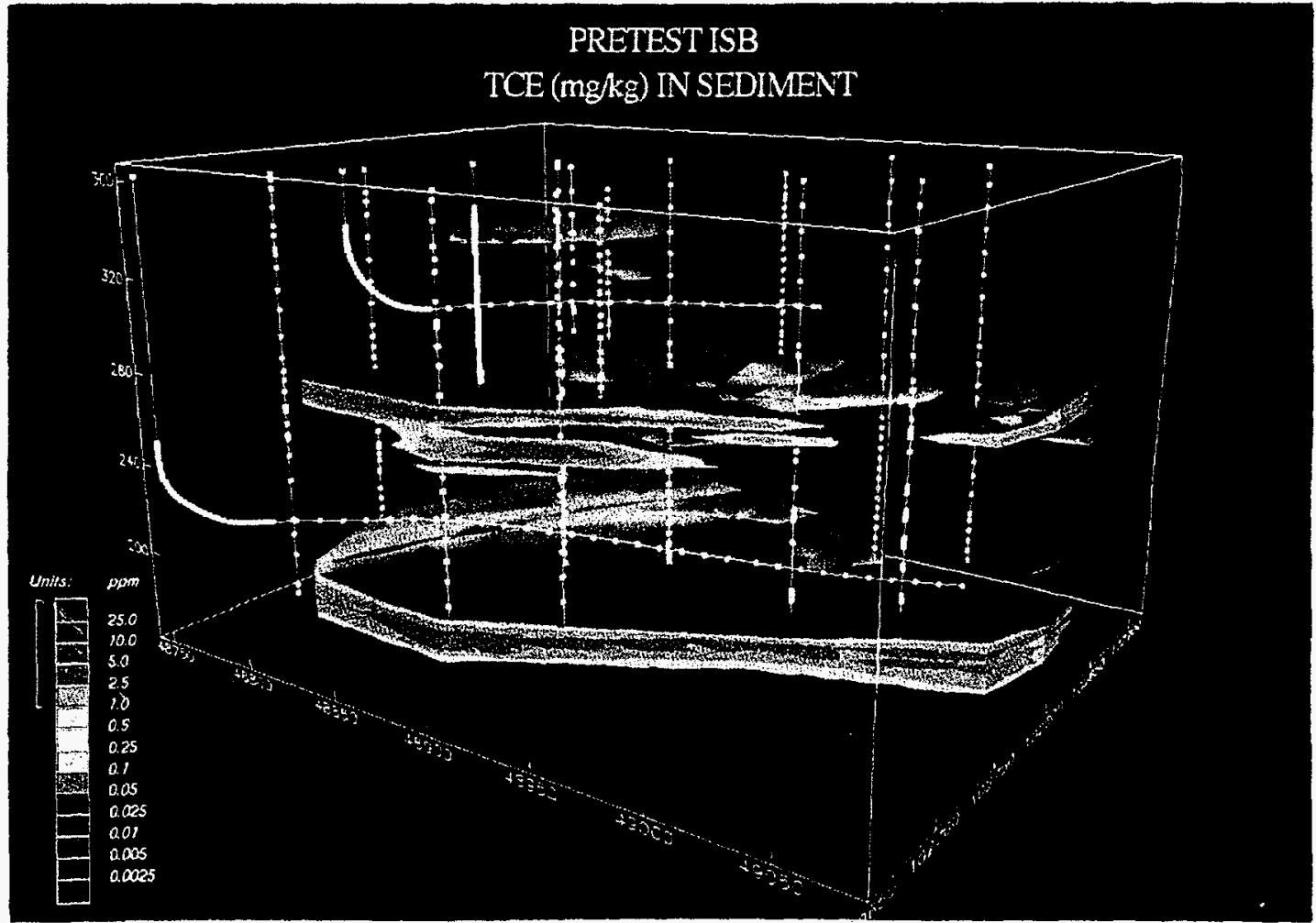

Figure 2. This three-dimensional portrayal shows the trichlorethylene concentration in sediment before the in situ bioremediation test. The intensifying color shows extremely dense saturations of TCE. This figure is roughly the size of a football field going down 200 feet and the concentrations are based on more than 800 sediment samples collected within the box. 


\section{POST TEST ISB \\ TCE (mg/kg) IN SEDIMENT}

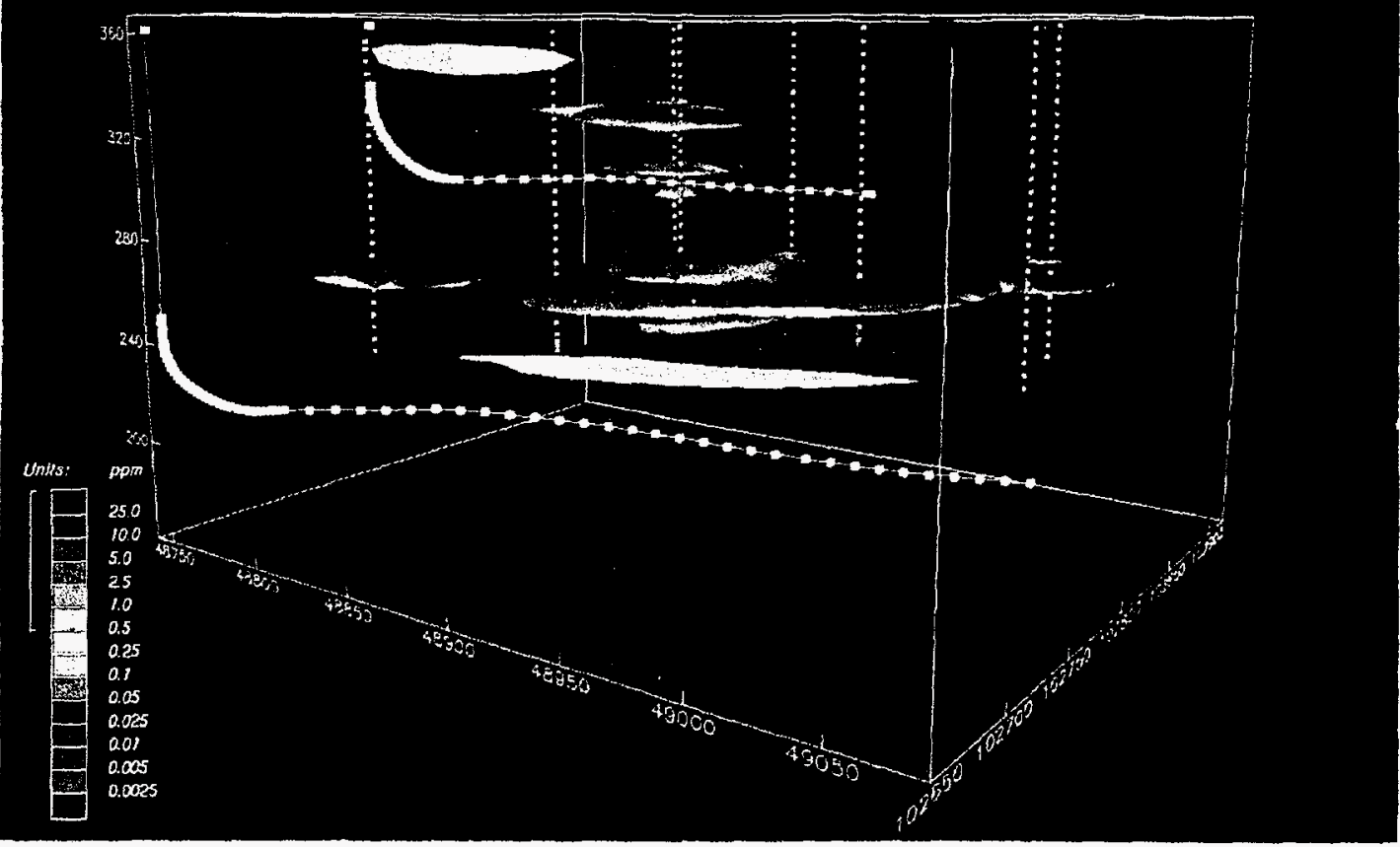

Figure 3. This three-dimensional portrayal shows the trichlorethylene concentration in sediment after the in situ bioremediation test. The concentrations of TCE are diminished greatly, and the overall size of the contaminant plume is decreased dramatically. This figure is roughly the size of a football field going down 200 feet and the concentrations are based on more than 800 sediment samples collected within the box.

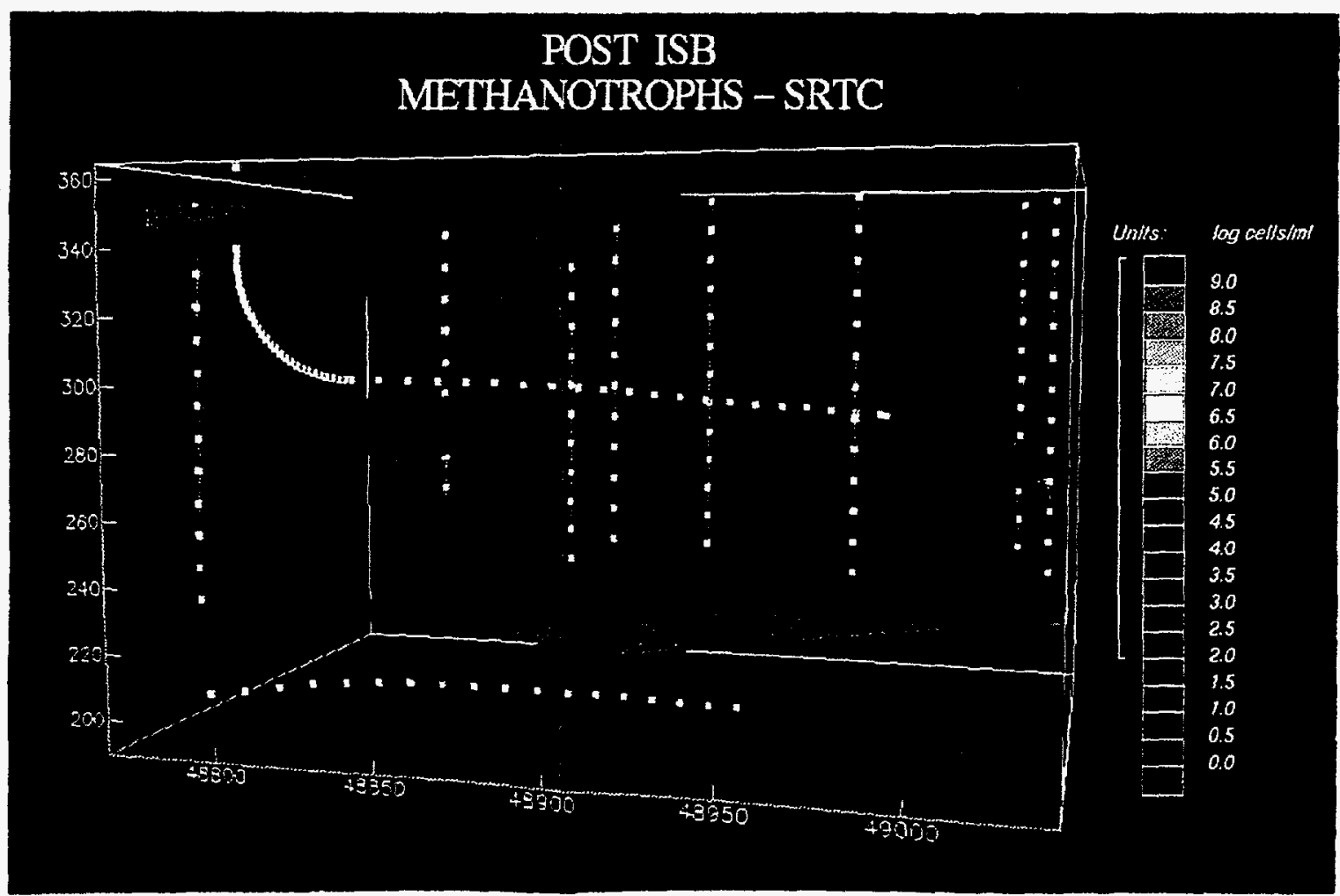

Figure 4. This portrayal shows the densities of methanotrophs (methane-oxidizing bacteria) after the in situ bioremediation test-after stimulation. Densities are in log units and pre-test densities were less than 10. The methantrophs' population is significant and appears in the correct location to the plume. This figure is roughly the size of a football field going down 200 feet and the concentrations are based on more than 800 sediment samples collected within the box. 
11a. Describe the principal applications.

This technology applies to contaminated sites around the world. The primary application of our technology is environmental remediation at sites where principal contaminants are chlorinated solvents. This technology can be used anywhere in the world where underground chlorinated solvent contaminants exist which are susceptible to aerobic microbial actions.

The contamination of soil and ground water with contaminants such as TCE and PCE is a widespread problem existing at more than 1600 government and industry sites in the United States. It is also a significant problem in industrialized countries around the globe.

According to a recent EPA paper (ref. 11), chlorinated volatile organic compounds are by far the most common organic contaminant. Most contaminated sites require both groundwater and soil remediation, and our technology addresses both of these. About 26 million cubic yards of soil, sludge, and sediment need to be cleaned up, just in $1600 \mathrm{U}$. S. sites.
The second-most common contaminant (after metals) on the National Priorities List of polluted sites is chlorinated volatile organic compounds such as TCE and PCE. Figure 5 gives the data.

11b. List all other applications.

Our demonstration test showed that this technique for bioremediation could be extended to other contaminants of similar composition, such as benzene, xylene, and toluene, or any biodegradable organic where $<10 \mathrm{ppm}$ cleanup standards are required.

\section{1c. List all potential applications.}

There are no other known applications for this technology which are not feasible. This technology works for any biodegradable organic solvent; the in situ approach makes the technology applicable in a wide variety of soils, geographical situations, and overall environments.

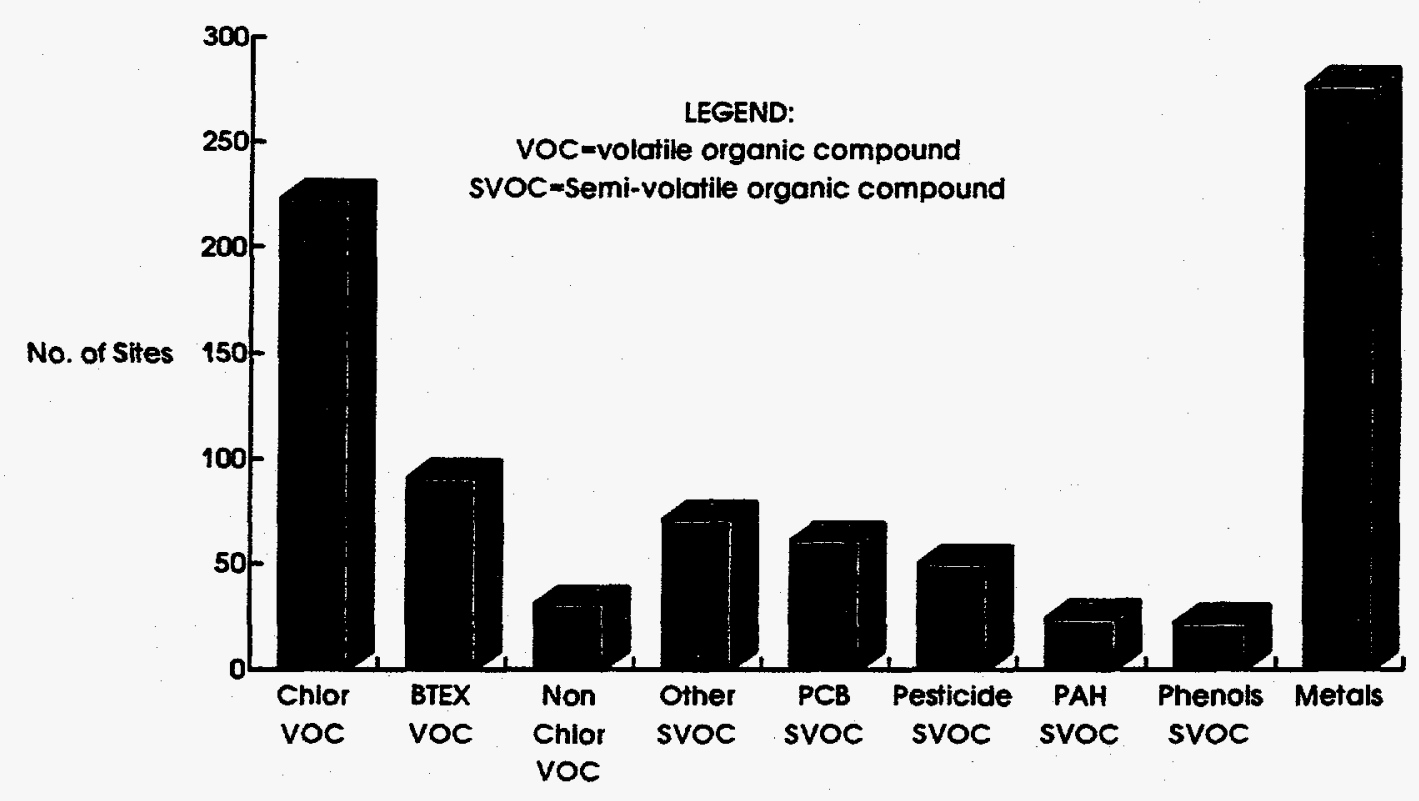

Figure 5. Frequency of Contaminants Present in National Priorities List Sites (Source: U. S. EPA, Technology Innovation Office, site assessment data, 1992.) 


\section{Summary.}

Our patented bioremediation process is already in use in industry. The process moved directly from full-scale demonstration to commercial application, with seven different environmental firms acquiring licenses immediately.

The potential savings from our bioremediation technology are so large as to be difficult to quantify in easily grasped numbers. For example, just in the demonstration area at the Savannah River Site-the area of a football field, 200 feet deepsavings over existing methods total $\$ 1.2$ million. For the 1600 sites in the U. S., savings would be in the billions. Worldwide, savings accumulate beyond billions.

Our technology resulted from one of the most comprehensive $R \& D$ projects ever performed in the field of environmental remediation. The overall project, of which our technique was the ultimate result, represents the best ideas and most rigorously tested methods collected from industry, government, and academic researchers in the country. The comprehensive base of integrated demonstrations of various remediation technologies upon which our technique rests has caused it to be an immediate commercial success.

The Department of Energy, which owns the Savannah River Site, has already granted seven commercial licenses to environmental firms, and a dozen more companies have either applied for a license to use this technology or have expressed a serious interest in it. In addition, a U. S. patent has been granted on our methane injection technology. SRTC holds two additional patents on the integrated horizontal well technology also.

Although various bioremediation processes have been demonstrated in the lab and in bioreactors, ours is the first to show full-scale applicability to in situ bioremediation for industrial sites. Our technology is a solution to environmental contamination which offers in-place destruction of contaminants without harmful side effects and delivers value for the money spent on the cleanup.

The technology lends itself to cost effectiveness because it is less capital intensive, takes less time than conventional means, incorporates conven- tional means to achieve remediation, and can be automated for low-cost and easy operation.

We see global applications for our technology: the microbe central to the process occurs naturally everywhere, and the types of contaminants it removes are chlorinated solvents that were used extensively in all industrial nations of the world.

In general, bioremediation enjoys wide public acceptance, and our specific technique is expected to be accepted by both the public and the regulatory agencies. It is a long-term solution to environmental cleanup which creates no harmful side effects and is perceived to be a natural process.

In summary, our technology works, and works effectively:

1. We showed that naturally occurring bacteria capable of degrading TCE/PCE can be stimulated in situ by adding relatively simple and naturally occurring nutrients.

2. We proved that biostimulation and biodegradation occurred in situ without production of toxic daughter products such as vinyl chloride.

3. Our automated process is easy to use.

4. The cost of adding the methane injection capability is low and is easily recovered during the lifetime of the remediation.

5. Gaseous nutrient injection represents a significant new delivery technique for in situ bioremediation.

6. Combined with air stripping, this technology represents a significant decrease in cost (about $50 \%$ ) and a significant improvement in efficiency (to undetectable levels) over conventional technologies (pump and treat, vapor extraction) now used for remediation of chlorinated solvent.

Remediation to drinking water levels $(<5 \mathrm{ppb})$ was achieved in less than half the time ( $<4$ years), at less than half the cost, with our in situ bioremediation technique than would have been possible with any existing systems. In fact, this bioremediation process may be the only one that can achieve drinking water standards at many sites. 
13. Chief Executive Officer
Name:
Dr. Susan Wood
Position:
Vice President and Director
Organization:
Westinghouse Savannah River Company
Address:
Savannah River Technology Center; 733-A
City, State, Zip:
Country:
Aiken, SC 29808
Phone/Fax:
United States of America
$803 / 725-3994 ; 803 / 725-1660$

14. Contact person to handle all arrangements on exhibits, banquet, and publicity.

Name:

Ellen L. Smith

Position:

Communicator

Organization:

Westinghouse Savannah River Company

Address:

Savannah River Technology Center; 773-A

City, State, Zip: Aiken, SC 29808

Country:

United States of America

Phone/Fax:

$803 / 725-3731 ; 803 / 725-4704$

15. To whom should reader inquiries about your product be directed?

Name:

Brian Hinman

Position:

Technology Licensing

Organization: Westinghouse Savannah River Company

Address:

Savannah River Research Campus

227 Gateway Drive

City, State, Zip: Aiken, SC 29803

Country:

United States of America

Phone/Fax:

803/652-1860; 803/652-1898

$1-800-228-3843$ 


\section{Appendix A \\ List of Additional Developers}

Submitter's name: Kenneth H. Lombard

Submitting organization: Westinghouse Savannah River Company

Address: $\quad$ Savannah River Technology Center

City/State/Zip/Country: Aiken, SC 29808 (USA)

Phone/Fax 803/725-6390; 803/725-6223

Submitter's name: $\quad$ Brian B. Looney

Submitting organization: Westinghouse Savannah River Company

Address:

Savannah River Technology Center

City/State/Zip/Country: Aiken, SC 29808 (USA)

Phone/Fax 803/725-3692; 803/725-7673

Submitter's name: $\quad$ Carl B. Fliermans

Submitting organization: Westinghouse Savannah River Company

Address:

Savannah River Technology Center

City/State/Zip/Country: Aiken, SC 29808 (USA)

Phone/Fax

$803 / 725-6420 ; 803 / 725-6223$

Submitter's name: $\quad$ Carol A. Eddy-Dilek

Submitting organization: Westinghouse Savannah River Company

Address:

Savannah River Technology Center

City/State/Zip/Country: Aiken, SC 29808 (USA)

Phone/Fax 803/725-2418; 803/725-7673 


\section{Appendix B \\ List of Supporting Documentation}

1. U. S. Patent 5,384,048. Bioremediation of Contaminated Groundwater. Filed March 8, 1994. Granted January 25, 1995.

2. Videotape, "Integrated Demo Closeout," Movie \#1

3. "Nuclear into Environmental: The Transformation of Savannah River," by Bruce M. Cadotte and Terry C. Hazen, ECON, December 1994

4. "Environmental Biotechnology: Business and Government Are Looking to Biotech for Answers About How to Clean Up the Environment," by Stephen M. Edgington, Biotechnology. Vol. 12, December 1994

5. "Preliminary Technology Report for In Situ Bioremediation Demonstration (Methane Biostimulation) of the Savannah River Site Integrated Demonstration Project," by Terry C. Hazen, WSRC-TR-93-670, Rev. 0.

6. "Cleanup of VOCs in Non-Atid Soils - The Savannah River Integrated Demonstration," published by the U. S. Department of Energy, Environmental Restoration and Waste Management, Office of Technology Development, WSRC-MS-91-290, rev 1.

7. "Commercialization Plan for In Situ Bioremediation Process Using Methane Injection and $\omega_{n}, x, j$ izontal Well Configuration," [TTP SR 1-0-11-01 Validation and Publication of SR-ID Bioremediation Activities In Situ Remediation Technology Development IP (GS091)], by Terry C. Hazen, Principal Investigator

8. "Test Plan for In Situ Bioremediation Demonstration of the Savannah River Integrated Demonstration Project," DOE/OTD TTP No: SR 0566-01 (U), September 18, 1991, revised April 23, 1992, Westinghouse Savannah River Company, Savannah River Site, Aiken, South Carolina, 29808. Prepared for the Department of Energy under Contract No. DE-AC09-89R180035.

9. "In Situ Remediation: Scientific Basis for Current and Future Technologies," Thirty-Third Hanford Symposium on Health and the Environment, Pasco, Washington, November 1994.

10. "Full-Scale Demonstration of In Situ Bioremediation of Chlorinated Solvents at SRS," by Terry C. Hazen, The South Carolina Engineer, Winter 1993.

11. "Cleaning Up the Nation's Waste Sites: Markets and Technology Trends," U. S. Environmental Protection Agency, EPA 542-R-02-012, April 1993 (not attached; for data source only). 